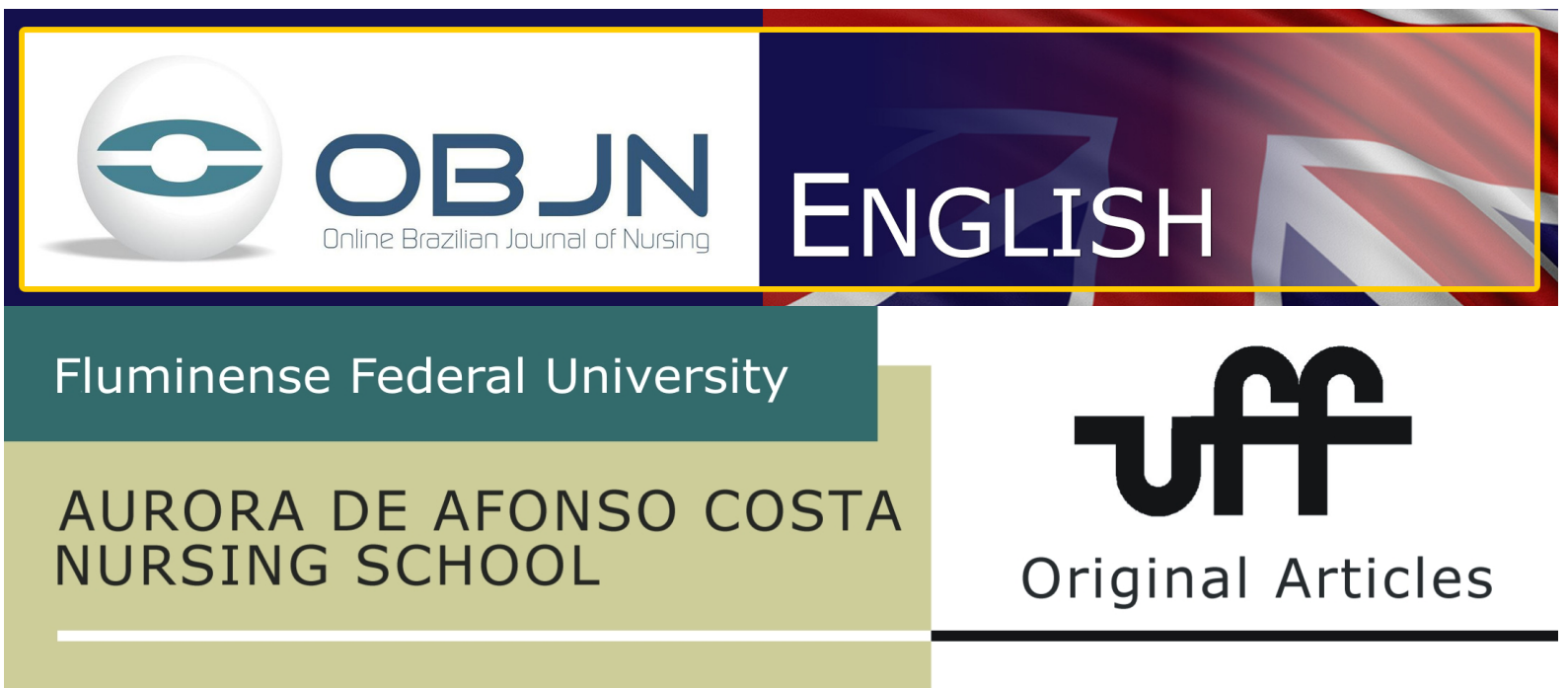

\title{
Mothers' \\ knowledge \\ concerning breastfeeding and complementation food: an exploratory study
}

\author{
Mirna Albuquerque Frota ${ }^{1}$, Cíntia Freitas Casimiro ${ }^{1}$, Patrícia de \\ Oliveira Bastos ${ }^{2}$, Osvaldo Albuquerque Sousa Filho ${ }^{3}$, Mariana \\ Cavalcante Martins ${ }^{4}$, Ana Paula Soares Gondim ${ }^{4}$ \\ ${ }^{1}$ University of Fortaleza \\ ${ }^{2}$ ELITE School, CE \\ ${ }^{3}$ Federal Board of Nursing \\ ${ }^{4}$ Federal University of Ceará
}

\begin{abstract}
Objectives: To investigate the dietary habits and the factors that influence the practice of exclusive breastfeeding in infants 0-6 months old.

Method: This is an exploratory study, in which we used a qualitative approach. Sample: 16 mothers of children under six months of age in mixed feeding, residing in Maranguape, CE. Data collection took place from July to October 2009 through semistructured interviews.

Results: we found a diet deficient in nutrients. The positive aspects regarding breastfeeding were praised, however it is noted that early weaning is justified by certain beliefs.

Conclusion: the performance of health professionals on infant feeding is relevant in order to promote breastfeeding and prevent possible damage to health, by conducting educational strategies aimed at the Community, trying to understand the reason for early weaning through the approximation with mothers, considering the peculiarities and the scene in which they operate.
\end{abstract}

Keywords: Breast Feeding, Supplementary Feeding; Child Health 


\section{INTRODUCTION}

Feeding a child has repercussions throughout life, which implies the need for care since birth, as the supply of breast milk exclusively for the first six months of life and, after this period, as a complement. This measure promotes nutritional adequacy and, therefore, promotes a healthy lifestyle, with beneficial implications in child growth and development ${ }^{(1)}$

Research conducted with 34,366 children younger than 1 year, in 2008, in the Brazilian state capitals and the Federal District (FD), noted an increased prevalence of exclusive breastfeeding (EBF) in babies under four months, from $35.5 \%$ in 1999 to $51.2 \%$. However, about a quarter of children between three and six months would already consume salty food $(20.7 \%)$ and fruits $(24.4 \%)$. On the other hand, $26.8 \%$ of children between 6 and 9 months, to whom solid/semi-solid foods would be recommended during this period, received no salty food ${ }^{(2)}$.

With regard to early weaning, beliefs such as "lack of milk" and "weak milk" are justifications for nursing mothers to start complementary feeding. Moreover, the sociocultural habits, conceptions of the family and external environment are arguments that promote negative influence on the practice of exclusive breastfeeding. The early introduction of foods in children's diets, prior to six months of age, reduces the duration of breastfeeding and interferes with the absorption of nutrients from milk that operate in the physiological metabolism, increasing the risk of contamination and allergic reactions ${ }^{(3.4)}$. Thus, it becomes imperative for the mother to know about the harmful effects so that the decision making is guided by a critical consciousness.

Based on the problems found, the following concerns emerged: Do mothers know the benefits of breastfeeding? When offering early complementary feeding, is the mother aware that the child's organism is not prepared to receive foods other than breast milk? In the period of complementary feeding, does the mother know the importance of breastfeeding up to 2 years of age? 
Faced with evidence of the practice of early dietary transition - exclusive breastfeeding to complementary feeding - it is essential to unravel the knowledge of mothers residing in rural areas and who are included in the group of economically disadvantaged families, aiming to understand the difficulties in continuing breastfeeding of children aged zero to six months, in order to develop actions that enable the continuation of breastfeeding.

The World Health Organization (WHO) emphasizes that the empowerment refers to individual actors, social groups or communities, combining measures intended to strengthen the capacities of actors, through the expression of their needs and concerns, and developing strategies for involvement in decision making. There is need for adequate information for the process of reflection and awareness about the current condition and formulation of the desired changes and condition to be built ${ }^{(5.6)}$.

Thus, regarding the promotion of healthy eating habits, the importance of food and nutritional education is unquestionable, despite the fact that reflections on the possibilities and limits are scarce in literature.

This study aims to: investigate dietary habits of children who are aged 0 to 6 months of age; identify factors that influence the practice of exclusive breastfeeding of children under six months of age, from a family Basic Health Unit of the Municipality of Maranguape - CE.

\section{METHOD}

This is exploratory research, in which we used a qualitative approach, since it recognizes the suffering, pain and anguish as manifestations of the objective conditions in which human collectives live ${ }^{(7)}$.

The study was conducted at the Family Health Strategy (FHS) included in a Basic Health Unit (UBASF, in Portuguese), located in the District of Sapupara, in the rural municipality of Maranguape, which is located in the metropolitan area, approximately $30 \mathrm{~km}$ from Fortaleza, Ceará, Brazil. The Health Unit serves approximately 700 families. 
The subjects were 16 mothers of babies under six months of age who were receiving mixed feeding, and their inclusion criteria are: to reside in that community and to be treated at the local UBASF.

Data collection was conducted between June and October 2009. We conducted a survey, through the Community Health Agents ( $\mathrm{CHA})$, with the participants who met the inclusion criteria and who were invited to attend an initial meeting to promote the interaction researcher-subject. In this meeting, the study objectives and ethical principles of the research were explained and those who agreed to participate in the research were asked to sign the Instrument of Consent (IC), according to Resolution 196/96 of the National Health Council ${ }^{(8)}$. The study was submitted to the Ethics Committee in Research of the University of Fortaleza (UNIFOR) and was approved under number 028/2007.

Home visits were scheduled according to the availability of the mother for the semistructured interview. Visits favored the observation and analysis of lifestyle, since they enabled the approach with the daily life of each participant. It is noteworthy that the annotations of the visits were recorded in the field diary.

The data were dealt with through content analysis, of which the method is characterized by the description and documentation of the interviewees' statements followed by their identification and categorization. The wealth of ideas and meanings - similar and different, the synthesis of thoughts, material exploration, interpretation and formulation of creative findings then proceeded ${ }^{(9)}$.

In the interviews recorded, the letter $M$ (mother) was assigned, followed by the serial number of the interviews (M1, M2, M3...).

\section{RESULTS}

The interviewees were aged between 17 and 39 years and the majority of them had not completed high school and were not working. As for household income, eight of the participants only earned a minimum wage. 
The analysis of the interviews allowed the construction of the following empirical categories: feelings related to breastfeeding; breastfeeding benefits; food offered; maternal beliefs; and external interference that affects exclusive breastfeeding.

In the category of feelings related to breastfeeding, the participants focused on positive aspects of breastfeeding, such as the perception of warmth and love.

Breastfeeding, for me, is the affection from mother to daughter. An act of love. (M2)

It's really good. For me, I think breastfeeding is the best thing; besides, it is healthy. (M7)

Very cool. It is an experience that can't be described, not really [...]. (M14)

The act of breastfeeding is a complete and successful experience; it is indescribable, especially pleasing. However, when the process of offering the breast becomes mechanical or an obligation according to the context in which the mother lives, the affection is masked by excuses.

I don't think so, at all. For me, the only thing it does is to stretch out the poor breasts, and it's not worse because I took a course before having this girl at the hospital where she was hospitalized. (M8)

[...] for me, it doesn't matter if you breastfeed or not [...]. Well, you know, it is an obligation that has to be done anyway. I don't care if I breastfeed or not. (M15)

In the category benefits of breastfeeding, the mothers mentioned several benefits grounded in biomedical discourse, mostly aimed at disease prevention.

It's because, I think, when we start giving other foods the child doesn't feel good, right? It feels bad. Its poop gets softer. But with the breast it doesn't happen; we don't have this problem because it's something that is healthy. (M5)

The child does not get sick so easily; it is more resistant [...]. It is important to him, right!? (M14)

The knowledge concerning protection against diseases is directly associated with the discontinuation of exclusive breastfeeding, starting from the early offer of 
complementary foods, that is, the mother understands that, when weaned early, the child presents signs that feature a compromised health state.

The best development of the dentition was characterized as a benefit of breastfeeding.

I think it's important; because of the teeth, right? She felt nothing when her teeth came through; she was breastfed up to two years. She won't suck all this time. (M4)

It's very important; because of his health; his period of teething, you know? [...] They cut well. (M9)

Another benefit offered by breastfeeding is the economic factor. Breastfeeding is, therefore, seen as a practice that reduces feeding expenses.

It does no harm at all, and it's also good for our pocket, right? 'Cause for six months we don't spend any money with alimentation. (M5)

It is so good, isn't it?; We save a lot of money. (M6)

In the category food offered, it was revealed that the eating practice of the child is based on milky meals, industrialized foods and juices, countering the precepts established by the WHO.

She sucks, takes Mucilon porridge and I also give her orange juice. (M4)

I give her milk, soup, porridge, yogurt, fruit, orange juice, acerola juice. (M5)

The mother had the habit of offering porridge to the child, which is a common practice, disseminated from generation to generation, when the recommendation is to offer, during the period of complementary feeding, breast milk rather than porridge to the child.

In addition, respondents offered foods without any nutritive value, containing colorants, when in fact the body of child aged between 0 and 6 months, is in the maturation phase since it is developing enzymes responsible for the digestion of complex substances. 
She sucks lollipop [...]. The girls give it to them [...] For instance, this morning she sucked a whole lollipop. (M13)

Everything she wants I give her; if she sees other kids eating something, and she wants it, I give it to her. My middle girl is kind of out of control [...] I give her chocolate, candies. I give her everything, even coffee. (M8)

As for the nutritional value of breastfeeding, when the rationale for the early introduction of complementary foods was characterized by the perception that milk did not sate the hunger of the child, the maternal beliefs category arose. It was observed that they brought with them the value that breastfeeding was useful to satisfy hunger; therefore, when they realized that such a situation did not occur, they felt insecure and inadequate, which led them to seek complementary feeding.

[...] I believe that the child continues to be hungry [...] because we give the breast and the girl still takes a bottle of porridge. (M11)

[...] I started to give him milk because he was not happy [...]. I gave him the breast, again and again and it wasn't enough. Then we came up with the idea of giving milk and voila! Then he quiets down. (M4)

She is not satisfied with milk, she keeps crying. (M10)

The method used to assess the baby's hunger is not accurate, because it regards hunger through crying and restless behavior of the child, which may suggest other necessities such as heat and pain, taking into account that the cry occurs for different reasons.

Well, because she takes the breast and yet she keeps crying with hunger, upset because she doesn't fill her tummy only with the breast. (M12)

I wasn't sure if she was really hungry [only with the breast milk] or not [...]. Uncertain about satisfying her hunger [only with breast milk] or not really [...]. Just in case, I started to give it. (M11)

Mothers, besides considering that their milk is not enough, showed themselves not very confident, because they claimed their milk was weak and would not meet the nutritional needs of the baby, according to reports:

It's good, isn't it? It's great, but I just wanted to breastfeed, but I have little milk, you know? (M10) 
I started feeding him because I thought my milk was not enough to breastfeed him, so, as he suckled a lot and was always crying, I thought it was weak milk, you know? It couldn't sustain him. I was troubled, willing to give him milk, tea, porridge. I wanted to buy milk and give it. (M6)

In this category, it is possible to associate another maternal perception to belief, when the mother argues that water should be offered to the baby, since she believes breast milk does not quench thirst.

[...] I had to give her water. She felt thirsty, then I just gave it to her. (M2)

'Cause I thought, you know, she was thirsty because of the weather [...] very hot. But it was a little. Now she's drinking more [water]. (M16)

Water can be characterized as a food supplement presenting little danger at first sight. However, water can confuse feelings of satiety and the child becomes vulnerable to contamination, and therefore it becomes relevant to investigate and evaluate the origin of it.

Another aspect was related to the weight of the child, identified as a significant factor in the decisions regarding the provision of exclusive breastfeeding. In general, the mother considers fat as a synonym for health as well as the vision of others as the main reference for decision making.

As for this one, he doesn't have diarrhea and is pretty chubby [...]. (M6)

Child who doesn't take the breast gets skinny. (M9)

She was very skinny, then, you know? People keep bugging us! Woman, you have to give food to this girl because she is too skinny. Soon she will be malnourished. (M5)

From the interviews, it is noted that there is disagreement in the relationship between breastfeeding and baby weight, so that some testimonies elucidate that breastfeeding fattens and, in other statements, that breastfeeding is insufficient for the child, portraying difficulties concerning the credibility of the effectiveness of the nutritional 
components of breast milk, that is, when the child is exclusively breastfed it shows it is healthy when it looks "chubby".

In the category external interference affecting exclusive breastfeeding, the influence suffered by the mother in the decision of offering complementary foods was observed in the reports, so that it was unanimous that the support from grandparents was important in the introduction of other foods in a period that would be of exclusive breastfeeding.

My mother used to say: girl, this boy is hungry. (M4)

This girl ate too much. She wanted to suck the whole night, but I couldn't get up to pick her up. Mom said [...] I'll give her porridge, because she sleeps longer. Then she would give her porridge and she would sleep almost the whole night. (M8)

Then my mother in law said: it's already time you give him some milk. (M9)

The father was classified as another opinion maker on the choosing of proper food. However, he presented himself as a positive aspect, when showing to be in favor of exclusive breastfeeding, and could be considered a significant instrument for the permanence of the mother in the act of breastfeeding.

My husband said this: be patient, because I thought you had no milk. (M6)

Thus, as the professionals during the consultation of prenatal and postpartum give fundamental guidelines on breastfeeding, the CHA are great allies, because they act directly in the community, identifying irregular practices and intervening appropriately.

It was a health agent who came to my house and warned me about breastfeeding, then I started to breastfeed her. (M3)

\section{DISCUSSION}

The act of breastfeeding is like a perfect fit between mother and child, fulfilling an external umbilical cord function, so that the woman who breastfeeds feels comfortable 
for perceiving the ability to continue generating life, as the food springs from the body. On the other hand, there are situations in which there is the need for the preparation of the woman-mother in contrast to the model of the assistentialism, which is a concept in which the guidelines do not prepare the woman to follow the path in a safe and autonomous way, providing a sense of unpreparedness and, consequently, nervousness emerges $^{(10,11)}$.

The ability to breastfeed is usually associated with biological factors and material limitations, which generates the feeling of inadequacy among women who cannot breastfeed $^{(11)}$. Nursing must reflect on how the guidelines are performed during prenatal consultation; to question whether the guidelines focus on the obligation of breastfeeding imperatively or if they are clarified by means of a dialogue in a horizontal model, allowing a critical reflection of the mother regarding the benefits of breastfeeding practices for both the mother and child.

Breastfeeding is usually connected to the field of biological factors and material limitations, making other more subjective issues unclear, leading to feelings of inadequacy in women who cannot breastfeed for their own issues that not always are accepted as valid for the professionals involved with breastfeeding.

The participants made a biomedical discourse to describe the benefits of breastfeeding, and this discourse was highlighted in another study, in which breastfeeding is placed as beneficial for the newborn for being associated with the fact that it meets the nutritional needs of the child for approximately the first six months of life, offers resistance against infections, provides a psychological bond between mother and child, among other features ${ }^{(12)}$.

The relationship between breastfeeding and teething of the toddler was considered in mothers' comments. It is noteworthy that, as this association has been proven, it is the reason for encouragement and relevance, since the mother who disseminates positive information favors the accession of others, enabling an improvement in breastfeeding rates. 
The duration of breastfeeding significantly influences the prevention of malocclusion, that is, children breastfed for periods greater than or equal to six months showed a lower incidence of dental malformations ${ }^{(13)}$.

The benefit of breastfeeding regarding economic factors could be a more emphasized strategy for the population groups living in a disadvantaged economic situation. In 2004, we calculated the average monthly expenses that a Brazilian mother would have if they bought milk to feed a baby in the first six months of life. The results showed a variation of $38 \%$ to $133 \%$ of the minimum wage, depending on the brand of the infant formula and ignoring other expenses arising from the purchase of bottles, teats and cooking gas, plus any expenses arising from diseases that are common in non-breastfed children ${ }^{(2)}$. In this context, the expenses can be reduced within the family if there is awareness, on the parents' part, to offer breast milk, which is economical, healthy and practical. In addition, other aggravating determinants would be the lack of knowledge and financial difficulties, which favor the purchase of low-cost infant formula, deemed harmful to children's health for presenting nutritional deficiencies.

The study has revealed a feeding practice based on lactic meals, industrialized foods and juices. Nevertheless, the Ministry of Health advises that only after six months should foods other than breast milk be introduced, because the body of the child is only ready to receive other types of food then. However, these foods should be specially prepared for children and it is not recommended to use processed foods such as beverages and dairy meals like porridge ${ }^{(14)}$.

The supply of foods rich in vitamin C, which provides protection against diseases, was also perceived in the dietary consumption of the children. However, due to the fact that the child does not receive the proper amount of breast milk recommended, the nutritional quality was low ${ }^{(15)}$.

The choice of a proper nutrition, rich in nutrients, mainly depends on the family and may have external influences such as television advertising, which influences the eating habits of the population, particularly children ${ }^{(16)}$. As for the eating habits based on industrialized foods, it occurs in the study population by external influences, a friendship and/or the 
desire of the child. This behavior can be reduced by parents if they are informed about the harm these foods can cause.

The in natura food commonly used in the past (fruit, vegetables, among others) are replaced by processed products, which in most cases consist of chemical substances such as colorants, antioxidants, flavorings, preservatives and others, that may be harmful to health ${ }^{(14)}$.

The mother's perception, when combined with the conception that the milk is weak and does not sustain her child, is a reason for premature discontinuation of breastfeeding, which may be a consequence of poor orientation of the health services ${ }^{(17)}$.

Another aspect identified as crucial in the provision of exclusive breastfeeding was the child's weight. A study ${ }^{(18)}$ that investigated the protective effect of breastfeeding against obesity in school-age of children breastfed for any period, has identified an obesity prevalence of $26 \%$; the majority of children and adolescents (92.6\%) were breastfed sometime in life, and of these, $78.8 \%$ received it for at least three months.

It is possible that mothers understand the weight as a factor of good health in children from zero to six months and, therefore, breastfeeding cannot be regarded as a determinant for later obesity.

As for the family interference in exclusive breastfeeding, it is worth highlighting that grandmothers can exert influence on breastfeeding, both in duration and exclusivity, which implies the presence of cultural factors in the breastfeeding process. Other studies, however, warn that the influence of the father on breastfeeding is, in general, underestimated and that, often, health professionals do not give enough priority to the preparation of future parents, who generally do not attend prenatal visits and other intervention actions ${ }^{(19,20)}$.

In this context, it is important to have a trained health care team to meet the concerns and doubts of mother and family in order to encourage exclusive breastfeeding for the recommended period.

\section{CONCLUSION}

Frota MA, Casimiro CF, Bastos PO, Sousa Filho OA, Martins MC, Gondim APS. Mothers' knowledge concerning breastfeeding and complementation food: an exploratory study. Online braz j nurs [Internet]. 2013 Apr [cited year mouth 131 day]; 12 (1): 120-34. Available from: http://www.objnursing.uff.br/index.php/nursing/article/view/3890 
The study made it possible to identify the eating habits of children living in rural areas and we perceived the early introduction of water, tea, porridge and processed foods that lacked nutrients.

Breastfeeding, when perceived as positive, prevailed in biomedical discourse, portraying the protection from diseases, influence on teething and economy of financial resources. On the other hand, it is negatively featured when the interruption of exclusive breastfeeding is justified because of beliefs such as change in aesthetics, the inability of the milk to satisfy the child, milk insufficiency and weakness, and/or by external influences of family members such as grandparents.

There are factors that hinder the effectiveness of the practice of exclusive breastfeeding, mainly because of the beliefs of mothers who promote the early introduction of foods. However, a cultural approach should be undertaken with caution, since this perception brings rooted values that pass from generation to generation.

As a limitation of the study the difficulty to know the socio-cultural influences that permeate the mother in the breastfeeding process should be mentioned, considering it is a process that needs to be investigated from an observation of the daily lives of individuals, focusing on routine activities and ambiguity of feelings and situations.

Thus, it an anthropological approach is suggested for future research, involving cultural factors in the benefits of breastfeeding for both mother and child. Furthermore in this context, it is necessary to evaluate how the guidelines are being conducted on breastfeeding during prenatal consultation, because the process of educating is somewhat specific, and it must unite scientific and popular knowledge in a dialogical perspective, fostering the autonomy of the individual.

Health professionals can intervene in the process to prevent possible damage to health through the use of educational strategies that aim to guide the community and promote improvement in quality of life. We highlight the performance of groups of pregnant women from the beginning of the pregnancy cycle to develop skills for effective 
breastfeeding and, after childbirth, make home visits aiming to provide clarifications to the families.

Professionals should be aware of the situations identified in the research, which may favor the early introduction of complementary foods, through reassessment of their professional practice as well as the development of plausible strategies, considering the peculiarities of individuals and scenarios.

\section{REFERENCES}

1. 1 Frota MA, Pordeus AMJ, Forte LB. Acompanhamento antropométrico de crianças: o ideal e o realizado. Rev baiana saúde pública. 2007;31(2):214-24.

2. Ministério da Saúde (BR). II Pesquisa de Prevalência de Aleitamento Materno nas Capitais Brasileiras e Distrito Federal. Brasília: Ministério da Saúde; 2009.

3. Polido CG, Mello DF, Parada CMGL, Carvalhaes MABL, Tonete VLP. Vivências maternas associadas ao aleitamento materno exclusivo mais duradouro: um estudo etnográfico. Acta paul enferm. 2011;24(5):624-30.

4. Saldiva SRDM, Escuder MM, Mondini L, Levy RB, Venancio SI. Práticas alimentares de crianças de 6 a 12 meses e fatores maternos associados. J pediatr (Rio J). 2007; 83(1):53-8.

5. World Health Organization. Health promotion in hospitals: evidence and quality management. Geneva: WHO; 2005.

6. Schiavo MR, Moreira EN. Glossário Social. Rio de Janeiro: Comunicarte; 2005.

7. Bosi MLM, Mercado FJ, organizadores. Pesquisas qualitativas de serviços de saúde. Petrópolis, RJ: Vozes; 2004.

8. Ministério da Saúde (BR). Conselho Nacional de Saúde. Resolução n. 196/96. Dispõe sobre pesquisa envolvendo seres humanos. Diário Oficial da União 16 out 1996.

9. Minayo MCS. O Desafio do Conhecimento: Pesquisa Qualitativa em Saúde. $12^{a}$ ed. São Paulo: Hucitec; 2010.

10. Antunes LS, Antunes LAA, Corvino MPF, Maia LC. Amamentação natural como fonte de prevenção em saúde. Ciênc saúde coletiva. 2008;13(1):103-9.

11. Silva RMR, Marcolino $C$. The experience of the breastfeeding/early weaning process by women orientated to breastfeeding: a qualitative study. Online braz $\mathrm{j}$ nurs [internet]. 2009 [cited 2011 Jun 27]; 8(1). Available from: http://www.objnursing.uff.br/index.php/nursing/article/view/j.16764285.2009.2019/ 460.

12. Araújo OD, Cunha AL, Lustosa LR, Nery IS, Mendonça RCM, Campelo SMA. Aleitamento materno: fatores que levam ao desmame precoce. Rev bras enferm. 2008;61(4):488-92.

13. Gimenez CMM, Moraes ABA, Bertoz AP, Bertoz FA, Ambrosano GB. Prevalência de más oclusões na primeira infância e sua relação com as formas de aleitamento e hábitos infantis. Rev dent press ortodon ortopedi facial. 2008;13(2):70-83.

14. Ministério da Saúde (BR). Guia alimentar para a população brasileira: promovendo a alimentação saudável. Brasília: Ministério da Saúde; 2008.

15. Ramalho IR, Henriques EMV. Consumo alimentar de crianças atendidas em ambulatório de nutrição de Unidade de Assistência Secundária em Fortaleza - Ceará. Rev bras promoç saúde. 2009;22(2):81-7.

16. Martins MC, Frota MA. Fatores que interferem na utilização dos alimentos regionais na cidade de Maranguape, Ceará. Cad saúde colet. 2007;15(2):169-82. 
17. Frota MA, Aderaldo NNS, Silveira VG, Rolim KMC, Martins MC. O reflexo da orientação na prática do aleitamento materno. Cogitare Enferm. 2008;13(3):403-9.

18. Siqueira RS, Monteiro CA. Amamentação na infância e obesidade na idade escolar em famílias de alto nível socioeconômico. Rev saúde pública. 2007;41(1):5-12.

19. Susin LRO, Giugliani ERJ, Kummer SC. Influência das avós na prática do aleitamento materno. Rev saúde pública. 2005;39(2):141-7.

20. Silveira FJF, Lamounier JA. Fatores associados à duração do aleitamento materno em três municípios na região do Alto Jequitinhonha, Minas Gerais, Brasil. Cad saúde pública. 2006;22(1):69-77.

Received: 16/04/2012

Approved: 05/02/2013 